\title{
max \\ Effects of Degreening Treatment on Quality and Shelf-Life of Organic Lemons
}

\author{
Vicente Serna-Escolano *(D), María José Giménez, María Emma García-Pastor (D), Alicia Dobón-Suárez, \\ Sofía Pardo-Pina and Pedro J. Zapata (1)
}

Citation: Serna-Escolano, V.; Giménez, M.J.; García-Pastor, M.E.; Dobón-Suárez, A.; Pardo-Pina, S.; Zapata, P.J. Effects of Degreening Treatment on Quality and Shelf-Life of Organic Lemons. Agronomy 2022, 12, 270. https://doi.org/10.3390/ agronomy12020270

Academic Editor: Dugald C. Close

Received: 27 December 2021

Accepted: 18 January 2022

Published: 21 January 2022

Publisher's Note: MDPI stays neutral with regard to jurisdictional claims in published maps and institutional affiliations.

Copyright: (C) 2022 by the authors. Licensee MDPI, Basel, Switzerland. This article is an open access article distributed under the terms and conditions of the Creative Commons Attribution (CC BY) license (https:// creativecommons.org/licenses/by/ $4.0 /)$.
Department of Agri-Food Technology, Polytechnic School of Orihuela, University Miguel Hernández, 03312 Alicante, Spain; maria.gimenezt@umh.es (M.J.G.); m.garciap@umh.es (M.E.G.-P.);

alicia.dobon@goumh.umh.es (A.D.-S.); sofia.pardo@goumh.umh.es (S.P.-P.); pedrojzapata@umh.es (P.J.Z.)

* Correspondence: vserna@umh.es

\begin{abstract}
Degreening treatment is used in early cultivars of the lemon crop in the Mediterranean area to enhance the commercially desired colour when fruits have reached the proper ripening stage for harvesting and marketing. In the organic market, temperature and relative humidity are controlled to promote the degradation of chlorophylls, allowing the visualisation of the lower layer formed by carotenoids. Although this is a stressful procedure, the degreening treatment showed greater results in terms of weight loss and firmness, the control of the respiration rate, total soluble solids, titratable acidity, and the total phenolic content in flavedo and juice compared to the non-treated lemons, without significant differences on the overall liking between both treatments. During postharvest storage, significant differences in fruit quality were observed compared to at harvest, due to the decreasing tendency observed on the quality parameters analysed along with development and on-tree fruit ripening. In conclusion, the results obtained suggest that the application of a degreening treatment in early cultivars of lemon would not lead to a detriment of fruit quality other than the quality changes associated with the on-tree fruit-ripening process.
\end{abstract}

Keywords: colour; phenolics; firmness; sensory analysis; physico-chemical traits

\section{Introduction}

Organic agriculture is a production system with technical bases and a regulation that combines tradition and innovation, being focused on improving sustainability and fair relationships throughout the supply chain [1]. Lemon (Citrus limon L. Burm.f.) is a fruit highly appreciated worldwide by consumers, who demand high fruit quality standards which largely affect their purchase preferences. Therefore, commercialisation standards establish that a lemon fruit has to present a yellowish colour and contain a minimum of $20 \%$ of juice, these being considered as the most important factors for consumers [2]. Nowadays, organic citrus production worldwide represents about $1 \%$ of the total citrus production. Spain is one of the main organic lemon producers, achieving around $20 \%$ of the total global lemon production $[3,4]$.

Degreening is known as the process of acquiring the yellow colour of the lemon skin, which occurs naturally during the fruit ripening process, mainly due to the exposure of fruits to low temperatures at night and during the morning dew. These environmental conditions promote the expression of unique temperature-specific transcription factors (TFs) known as CIERF3, and shared TFs, such as CIbHLH25, among others. The expression of several genes associated with chlorophyll degradation, carotenoid metabolism, photosystem disassembly, and phytohormones leads to skin degreening $[5,6]$. However, lemon crops in areas of temperate climates show degreening problems related to the absence of low temperatures. These problems cause a delay in colour changes in early cultivar lemons at the ripe stage, although the skin is still green. Thus, the degreening treatment developed 
in controlled chambers is considered as one of the postharvest strategies used to promote the optimal harvest time of lemon fruits independently of environmental conditions. In organic production, temperature, relative humidity, and carbon dioxide concentrations are controlled during the postharvest storage of lemon fruits until they change their skin colour from green to favourable yellow, since nowadays the exogenous application of ethylene is banned [7].

Degreening treatment is considered an effective strategy to control fruit colour. It has been highly studied [8-10], although its effects on internal and external fruit quality are still unknown. Some studies have reported that the temperature and relative humidity applied during the degreening process decreased the organoleptic fruit quality. In particular, temperature changes resulted in flavour changes in oranges and mandarins [11]. In oranges, the degreening treatment modifies the normal respiration rate and ethylene production. In addition, it induces the production of volatile compounds, such as acetaldehyde and ethyl octanoate, leading to an undesirable odour $[12,13]$. Furthermore, the degreening treatment affected the expression of genes related to cellulase and flavonoid biosynthesis in citrus [12]. Moreover, a decrease in the total soluble solids and titratable acidity in oranges and mandarins was observed [14]. Finally, Baldwin et al. [10] observed that high temperature and relative humidity conditions promoted the activity of Penicillium digitatum in oranges, significantly increasing the incidence of fruit decay.

Some lemon fruits are more susceptible to decay than others during the degreening treatment. This fact could be related to the accumulation of water and the distribution of sugars, organic acids, and phenolics at the latest stage of the on-tree lemon fruit development [15]. There are several dependent factors: the combination of cultivar and rootstock, the absorption capacity and the distribution of water throughout the plant, the translocation from leaf to fruits, and the environmental conditions, among other factors $[16,17]$. Furthermore, these factors are influenced by agronomic practices, as some growers often use strategies to accelerate fruit growth, leading to an early harvest date, drastically reducing the lemon fruit quality. All of these key factors could cause significant differences in the quality characteristics of lemon fruits during the senescence process [18]. Other studies have elucidated the importance of total soluble solids and titratable acidity in oranges and mandarins stored under cold conditions, observing the greatest quality properties in those fruits with the highest content of these parameters $[19,20]$. Finally, the antioxidant system, mainly phenolic content and antioxidant enzyme activities, plays an important role in maintaining fruit quality during cold storage. The enhancement of the antioxidant system has been related to a quality improvement in cherries [21], plums [22], pomegranate [23], and lemon fruits [15]. Therefore, the main aim of this study was to clarify the effect of degreening postharvest treatment on the physico-chemical and sensory quality of organic lemon fruit compared to non-treated fruits.

\section{Materials and Methods}

\subsection{Experimental Design and Postharvest Storage Conditions}

This study was performed in a commercial orchard located in Cartagena (Murcia, Spain) under organic certification. Meteorological conditions showed a mean temperature and relative humidity of $18{ }^{\circ} \mathrm{C}$ and $73 \%$, respectively, while the rainfall was $47.6 \mathrm{~mm}$ per day during the 2019-2020 growing season. The 'Fino' lemon cultivar grafted on an 8 to 10-year-old Citrus macrophylla rootstock was the combination selected for this experiment. A randomised block design with three replicates distributed at different parts of the orchard including 25 trees for each replicate was set up (75 trees in total). Agronomic practices were carried out during the experiment according to the standard cultural criteria. After a physiological process of fruit abscission, which occurred at the beginning of July, the evolution of fruit quality parameters during development and on-tree ripening was performed. Two lemons from each tree (150 lemon fruits in total) with homogeneous size, colour, and without any visual imperfections were harvested and evaluated weekly. Determinations of fruit volume, colour, firmness, respiration rate, total soluble solids (TSS), 
and titratable acidity (TA) were carried out. Six longitudinal portions of flavedo were taken from each fruit, frozen in liquid $\mathrm{N}_{2}$, ground, and stored at $-80^{\circ} \mathrm{C}$. Moreover, $1 \mathrm{~mL}$ of juice from each sample was taken and stored until the phenolic compounds were quantified.

The first harvest date was established according to commercial practices on 9 September, when the lemon fruits showed a green colour and were around $55 \mathrm{~mm}$ in diameter. The first harvest represented around $25 \%$ of the total yield per tree. The lemon fruits were transferred within $2 \mathrm{~h}$ and degreening treated in a chamber at $25^{\circ} \mathrm{C}$ and a relative humidity (RH) of 90-95\% for 8 days. The second harvest date was performed on 9 December, when the lemon fruits showed an optimal commercial ripening stage in terms of fruit size and colour, although the degreening treatment was not applied. Then, five lots of 10 fruits without any physical damage and homogeneous in size and colour were selected for each of the three replicates and stored at $10{ }^{\circ} \mathrm{C}$ and $85-90 \%$ RH. After $0,7,14,21$, and 28 days of storage, one lot of 10 lemon fruits for each replicate was taken randomly for analytical determinations.

\subsection{Descriptive Sensory Analysis}

A descriptive sensory analysis was performed with a trained panel. Ten panellists, five men and five women, from the Agri-Food Technology department of the University Miguel Hernández of Elche (Orihuela, Alicante, Spain), were selected to evaluate the fruit quality of degreening-treated and non-treated lemons after 28 days of cold storage. Panellists received two preliminary $60 \mathrm{~min}$ orientation sessions in order to discuss the main sensory parameters demanded by consumers. The following attributes were evaluated: calyx abscission, oleocellosis, turgor, lemon aroma, overall aroma (detecting fruit senescence), skin oiliness, roughness, colour, and fruit decay. Overall liking is related to the satisfaction level of the panellists after considering all the previous parameters. The study was conducted in a standardised testing room of the $\mathrm{UMH}\left({ }^{\circ} \mathrm{C}\right.$ and $\%$ relative humidity) with 15 normalised sensory cabins. Thirty lemon samples per treatment were randomly selected to individually evaluate the sensory attributes selected at room temperature according to Habibi et al. [24]. A 10-point scale was used for each attribute analysed, where 0 represented no perceptible intensity and 10 extremely strong intensity. This scale is widely used by Spanish panellists, evaluating a broad range of sensory attributes. An evaluation session (1 h) was carried out where each panellist described the appearance and odour attributes of all samples.

\subsection{Physico-Chemical and Quality Parameters}

Lemon volume (V) was calculated by measuring fruit width (a) and length (b) on the equatorial perimeter, and fruit height (c) from the calyx to the end of the mamelon using a digital calliper (Mitutoyo: Kanagawa, Japan). The fruit volume was expressed in $\mathrm{mm}^{3}$, applying the following formula (1):

$$
\mathrm{V}=(4 / 3) \pi \mathrm{abc}
$$

The respiration rate was analysed at room temperature, placing each lemon fruit on a $0.5 \mathrm{~L}$ glass jar for $60 \mathrm{~min}$. Then, $1 \mathrm{~mL}$ of the atmosphere generated in the headspace was sampled and the $\mathrm{CO}_{2}$ content was quantified using a Gas Chromatograph (Shimadzu: Kyoto, Japan) coupled with a thermal conductivity detector. The results were expressed in $\mathrm{mg} \mathrm{CO} \mathrm{CO}_{2} \mathrm{~kg}^{-1} \mathrm{~h}^{-1}$, according to Martínez-Esplá et al. [22]. Weight loss was determined using a Radwag WLC 2/A2 balance (Radwag wagi Elektroniczne: Radom, Poland) with a precision of two decimal places. The results were expressed as the percentage (\%) of weight loss for each fruit regarding its initial weight. Firmness was measured using a TX-XT2i Texturometer (Stable Microsystems, Godalming, UK) coupled to a flat steel plate whose strength allowed a 5\% deformation at the equatorial region of the lemon. Results were expressed as $\mathrm{N} \mathrm{mm}^{-1}$. Colour $\mathrm{a}^{*}$ parameter was measured at three points along the equatorial fruit perimeter by using a Minolta colourimeter (CRC400, Minolta, Osaka, Japan). This parameter is related to fruit colour changes from green to yellow. All of 
these parameters were measured individually for each replicate, and the results were the mean \pm SE.

The content of TSS was quantified in each juice sample using a digital refractometer (Hanna Instruments, Woonsocket, RI, USA). Moreover, TA was measured in the same juice sample by the automatic titration (785 DMP Titrino, Metrohm, Herisau, Switzerland) of $0.5 \mathrm{~mL}$ juice neutralised with different volumes of $0.1 \mathrm{~N} \mathrm{NaOH}$ until a $\mathrm{pH}$ of around 8.1 was achieved. The results of both parameters were the mean $\pm \mathrm{SE}$, and were expressed as ${ }^{\circ}$ Brix and g citric acid equivalent $100 \mathrm{~mL}^{-1}$ for TSS and TA, respectively.

\subsection{Total Phenolic Quantification}

Total phenolics were extracted from flavedo samples by homogenising $2 \mathrm{~g}$ of tissue in $15 \mathrm{~mL}$ of water: methanol (2:8) containing $2 \mathrm{mmol} \mathrm{L}^{-1} \mathrm{NaF}$ in order to inactivate the polyphenol oxidase enzyme activity. The homogenate extract was centrifuged at $15,000 \times g$ at $4{ }^{\circ} \mathrm{C}$ for $15 \mathrm{~min}$. Then, the total phenolics were quantified in the supernatant. In addition, the total phenolic content of the juice samples was also measured. All analyses were carried out in duplicate using the Folin-Ciocalteau reagent, as previously reported [15]. Results were expressed as the mean $\pm \mathrm{SE}$ in g gallic acid equivalent (GAE) $100 \mathrm{~g}^{-1}$ of fresh weight (FW).

\subsection{Statistical Analysis}

Statistical analysis was carried out in three randomised replicates for all analytical parameters studied. Results were expressed as the mean $\pm \mathrm{SE}$. Data related to postharvest experiments were subjected to analysis of variance (ANOVA), and a multiple comparison test was performed using the Fisher LSD method to determine significant differences at $p<0.05$ between treated and non-treated lemons. Furthermore, mean comparisons were performed using a multiple range test (Tukey's HSD) to analyse whether the differences among treatments were significant at $p<0.05$ for descriptive sensory evaluation. All analyses were performed using the SPSS software, package version 22.0 for Windows (IBM Corp., Armonk, NY, USA).

\section{Results and Discussion}

The results of the descriptive sensory analysis showed that degreening-treated lemon fruits stored for 28 days at $10^{\circ} \mathrm{C}$ had an overall liking similar to non-treated fruits. Furthermore, treated lemon fruits showed higher turgor, lemon aroma and skin oiliness than non-treated fruits. Considering the negative effects on quality parameters, degreening treatment increased calyx abscission and provided odours related to fruit senescence. In addition, the incidence of oleocellosis in degreening-treated lemons was greater than in non-treated fruits since maybe the skin oil glands were more exposed due to the higher skin turgor detected in those lemons. Therefore, the postharvest handling of those lemon fruits should be carried out carefully to avoid the black spots caused by essential oil emissions after the rupture of the oil glands. In contrast, fruit decay incidence was significantly higher $(p<0.05)$ in non-treated lemon fruits than in the treated ones. Finally, other fruit quality parameters, such as colour or skin roughness, did not show significant differences $(p<0.05)$ between both treatments (Figure 1).

Lemon fruit reaches the optimal ripening stage before the yellow colour appears on its skin and is usually harvested when the skin is still green. This fact has a negative impact on customer preferences [25]. Degreening treatment depends on the temperature and relative humidity conditions of the storage chamber, leading to an increase in economical profits for growers since the harvest season could be extended as well as the satisfaction that consumers demand [26]. However, the degreening process has been associated with quality losses in fruits exposed to those conditions at $25{ }^{\circ} \mathrm{C}$ and $95 \% \mathrm{RH}$. In Citrus species, increases in fruit weight and calyx losses, fruit decay, undesired aromas, and flavours related to fruit senescence have been published as negative effects associated with degreening treatment $[8,27]$. Furthermore, the reduction in fruit quality would have a negative impact 
on growers mainly due to the competitiveness with international markets. Thus, the control of the degreening postharvest treatment is needed at the moment of application [26]. On the contrary, recent studies have reported that the degreening process in Citrus fruits did not deteriorate the overall fruit quality $[13,28]$. Due to the contradictory results in the overall liking previously reported, further research is required to fill this knowledge gap.

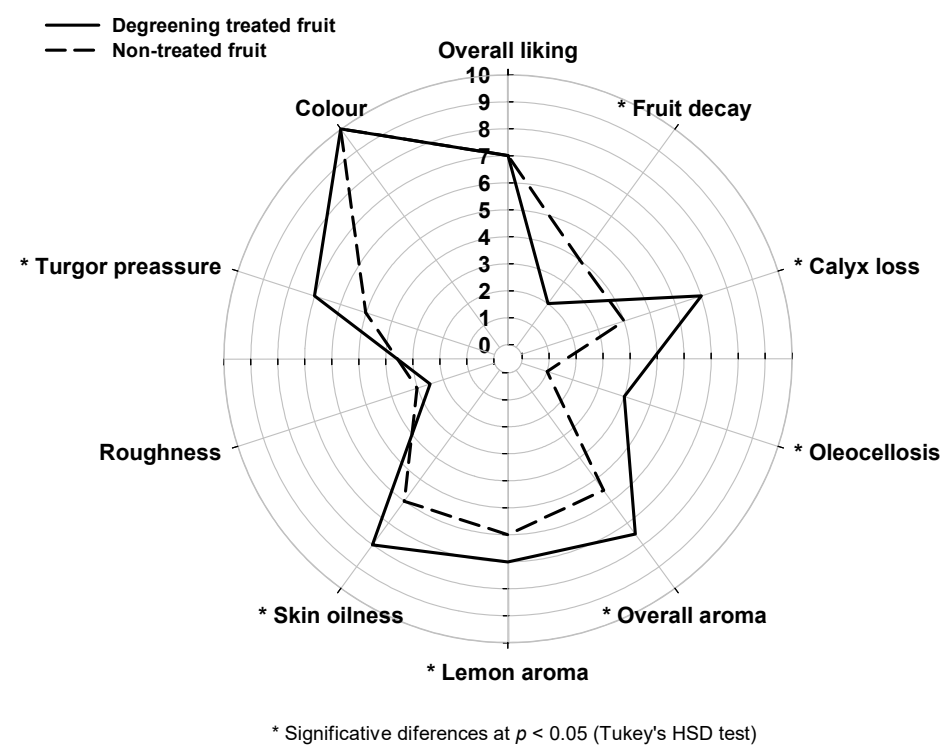

Figure 1. Descriptive sensory analysis of degreening-treated and non-treated lemon fruits in the 2019 experiment. Calyx abscission, turgor, lemon aroma, general aroma, skin oiliness and roughness, colour, oleocellosis and fruit decay were evaluated by trained panellists using a hedonic scale from 0 to 10 points. Asterisks ${ }^{*}$ ) show significant differences between treated and non-treated fruits at $p<0.05$ (Tukey's HSD test).

In general terms, lemon fruit quality based on physico-chemical and sensory properties decreased during cold storage for fruits both treated and non-treated; the fruit overall liking was negatively affected. However, the positive evolution of turgor and fruit decay was observed by trained panellists in degreening-treated lemon fruits (Figure 1). These results are in accordance with those reported by Morales et al. [28] on 'Owari' and 'Navelina' oranges. These authors observed that the degreening process did not reduce the internal or external fruit quality and, on the contrary, this treatment significantly improved $(p<0.05)$ the overall liking of consumers, highlighting the importance of harvest fruits at the optimum growth and ripening stage.

The weight loss of the lemon fruit is related to the senescence process and is one of the most important parameters for consumers [29]. Weight loss increased during cold storage in all samples studied and significant differences $(p<0.05)$ between both treatments were observed after 21 days of storage. At the end of the postharvest storage, non-treated lemon fruits reached a $24 \%$ higher weight loss than treated lemons (Figure 2A). These differences between both treatments could be related to differences in the transpiration process throughout the lemon fruit skin [30]. Besides, differences in fruit respiration rates at harvest (day 0) between both treatments (Figure 2B) are mainly influenced by the temperature of $25^{\circ} \mathrm{C}$ applied during degreening treatment. On the other hand, it could be related to the decrease observed during development and on-tree ripening (Figure 3). It is important to highlight that the respiration rate of lemon fruits increased $10 \%$ after the degreening process, although it was $20 \%$ lower than non-treated fruits after 14 days of storage. These results could be an indicator of a lower fruit metabolic rate in degreeningtreated lemons, which could be related to a reduction in the activities of the catalytic enzymes involved during the fruit senescence process [31]. 


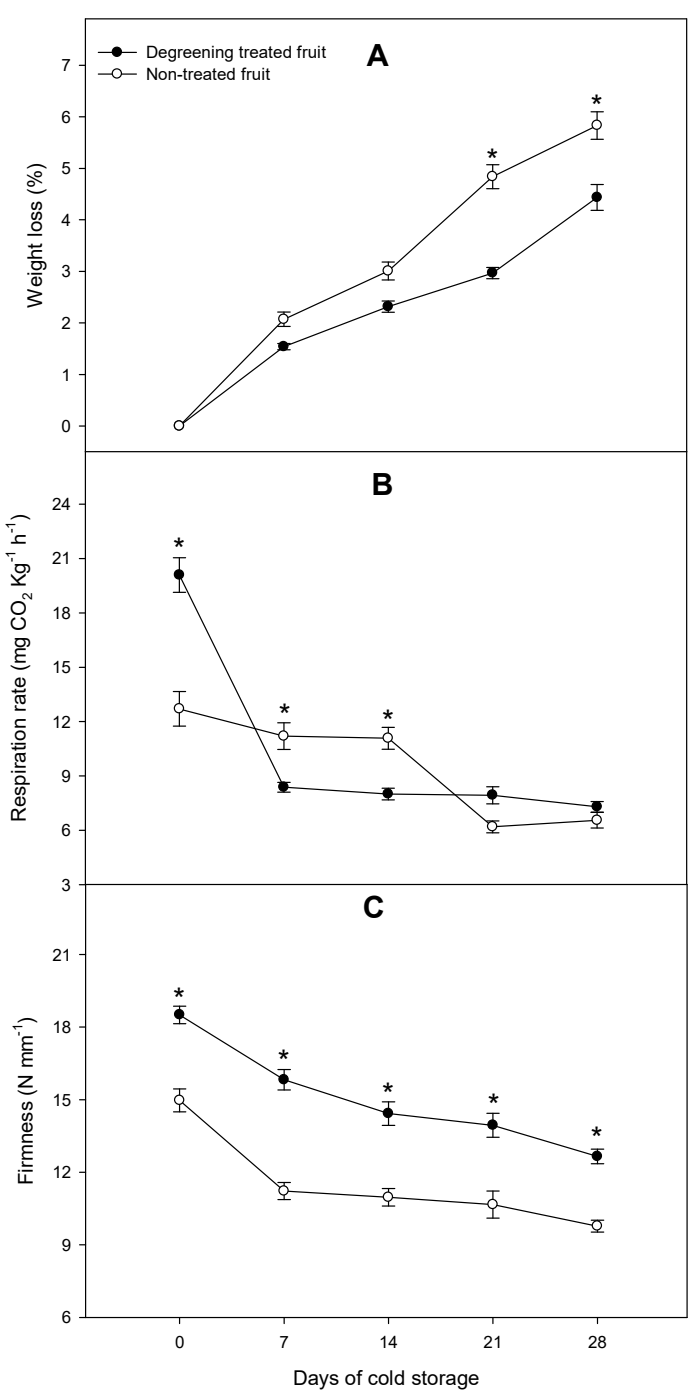

Figure 2. Effect of degreening treatment on weight loss (A), respiration rate (B), and firmness $(\mathbf{C})$ in lemon fruits stored during 28 days at $10^{\circ} \mathrm{C}$. Asterisks $\left(^{*}\right)$ show significant differences between treated and non-treated fruits at $p<0.05$.

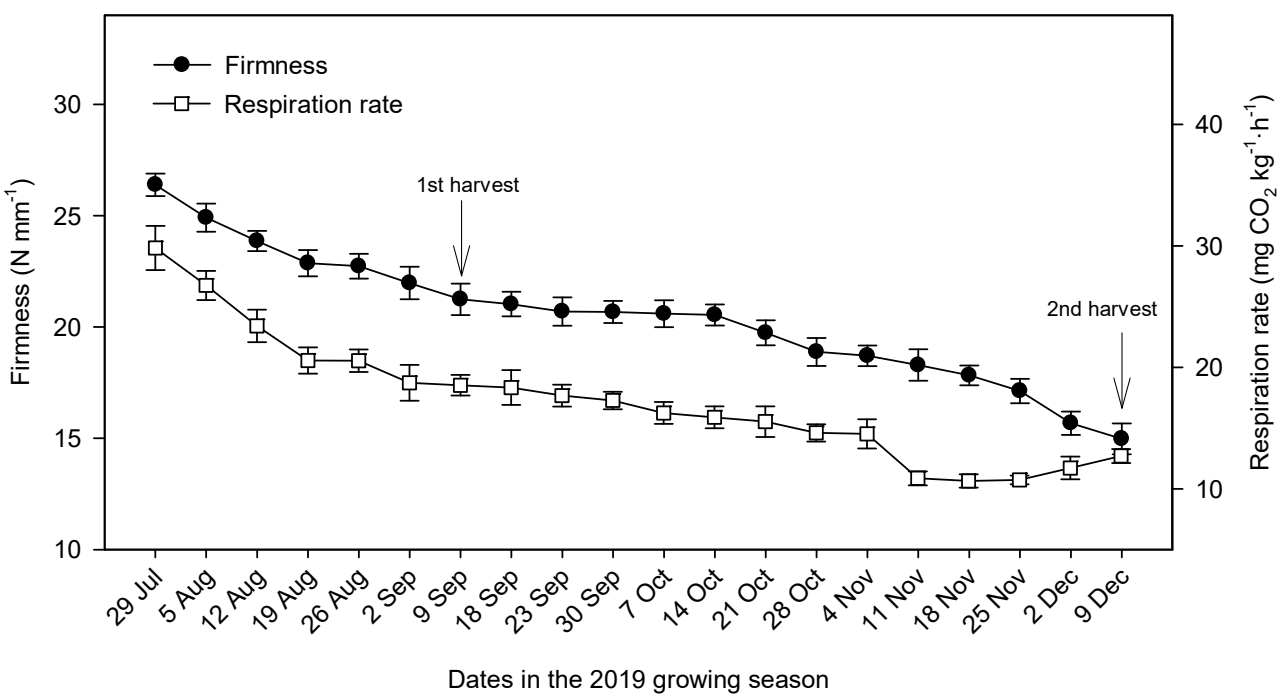

Figure 3. Evolution of firmness and respiration rate represented at the left and right axes, respectively, in lemon fruits during development and on-tree ripening in the 2019 growing season. 
Firmness is directly related to cell turgor and skin thickness, two crucial characteristics for overall fruit acceptance by consumers [32,33]. Values of firmness decreased during postharvest storage for both treatments, although those values of degreening-treated lemon fruits were $20 \%$ higher than the non-treated fruits at harvest or day 0 . These differences observed were related to the harvest point and the on-tree ripening process, as can be observed in Figure 3. Indeed, regarding the evolution of firmness during postharvest storage, these differences were maintained between both treatments during 28 days of storage (Figure 2C).

Firmness loss throughout the fruit development and on-tree ripening as well as during postharvest storage could be related to the activation of the main hydrolytic enzymes: polygalacturonases, pectin methyl esterases, and cellulases. It has been described that the main role of these enzymes is attributed to the depolymerisation of the main cell wall components of flavedo and albedo tissues, such as pectins, hemicellulose, and cellulose, being that their expressions increased during the fruit senescence process $[19,34]$.

Concerning colour $\mathrm{a}^{*}$, its values ranged from -20 to -18 until 11 November, the first harvest date being on 9 September when the lemon fruits were still green (Figure 4). Degreening is a natural process related to the degradation of chlorophylls leading into the biosynthesis of carotenoids, which occurs when temperatures decrease below $13{ }^{\circ} \mathrm{C}[25]$, being in accordance with the presented results (Figure 4). Besides, not only the temperature but also the selected cultivar, rootstock, relative humidity and type of soil are key factors that affect this natural process [35]. At the beginning of the storage experiment, the colour was similar for both treatments and no significant differences were observed $(p \geq 0.05)$ (data not shown). In addition, the fruit volume gradually increased during the 2019 season (Figure 4).

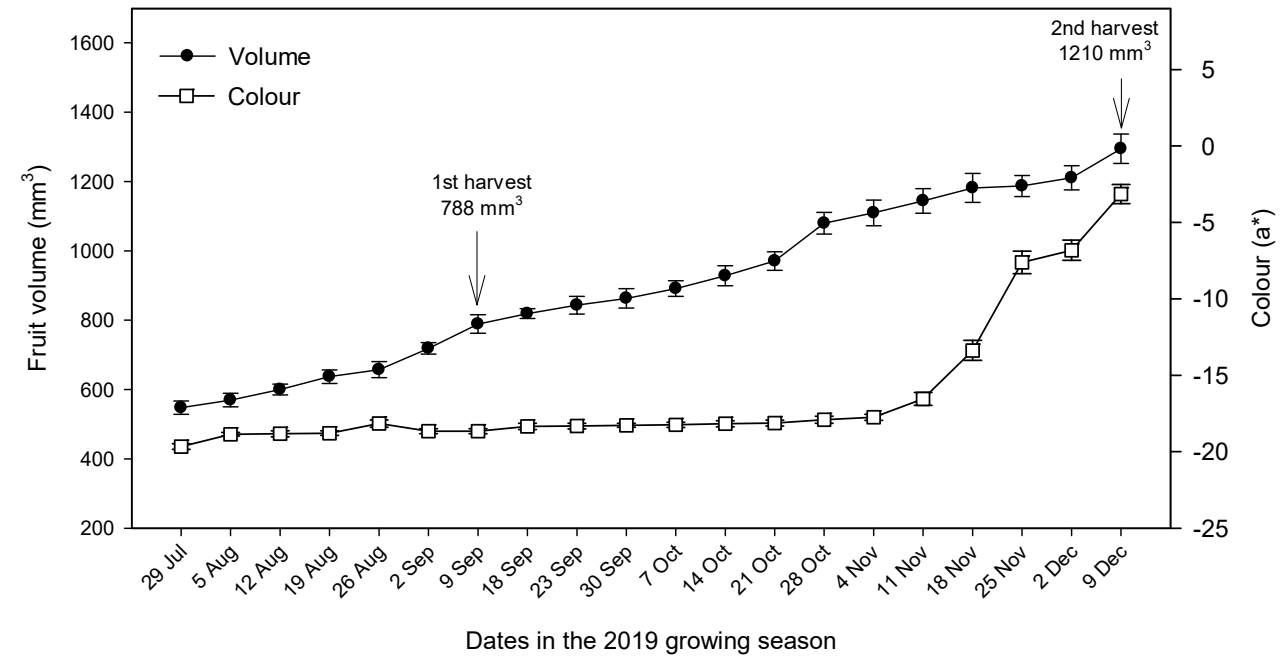

Figure 4. Evolution of fruit volume and colour represented at the left and right axes, respectively, in lemon fruits during development and on-tree ripening in the 2019 growing season.

The content of TSS and TA at harvest were $12 \%$ and $4 \%$ significantly higher $(p<0.05)$, respectively, in degreening-treated lemon fruits than non-treated fruits, those differences being maintained throughout the postharvest storage period. Moreover, the results showed that degreening treatment did not significantly affect $(p \geq 0.05)$ TSS and TA content (Figure 5A,B, respectively), similar results as those concluded by Sdiri et al. [11].

Differences between both treatments on TSS and TA content observed at harvest (Figure 5A,B, respectively) could be related to the evolution of these physico-chemical parameters studied during the development and on-tree ripening, since both parameters decreased $31 \%$ and $26 \%$, respectively (Figure 6). This fact has been associated with the ratio between the compounds translocated from leaves to fruits and the water absorption in 'Femminello' lemons [36]. In this sense, lemon fruits showed a two-fold increase in their 
initial fruit volume at the end of the experiment, without negatively affecting negatively the harvest date that took place on 9 September (Figure 4). Nevertheless, contradictory information has been reported about the evolution of TSS content in preharvest fruits. Sun et al. [37] did not observe significant differences $(p \geq 0.05)$ among lemon fruits harvested at different fruit development stages, highlighting the influence of cultivar, agronomic practices and environmental conditions. Furthermore, TA content is related to the major organic acids-citric acid, malic acid, and fumaric acid-that are used as a carbon source in the pyruvate decarboxylation reaction for the maintenance of cellular homeostasis $[37,38]$.

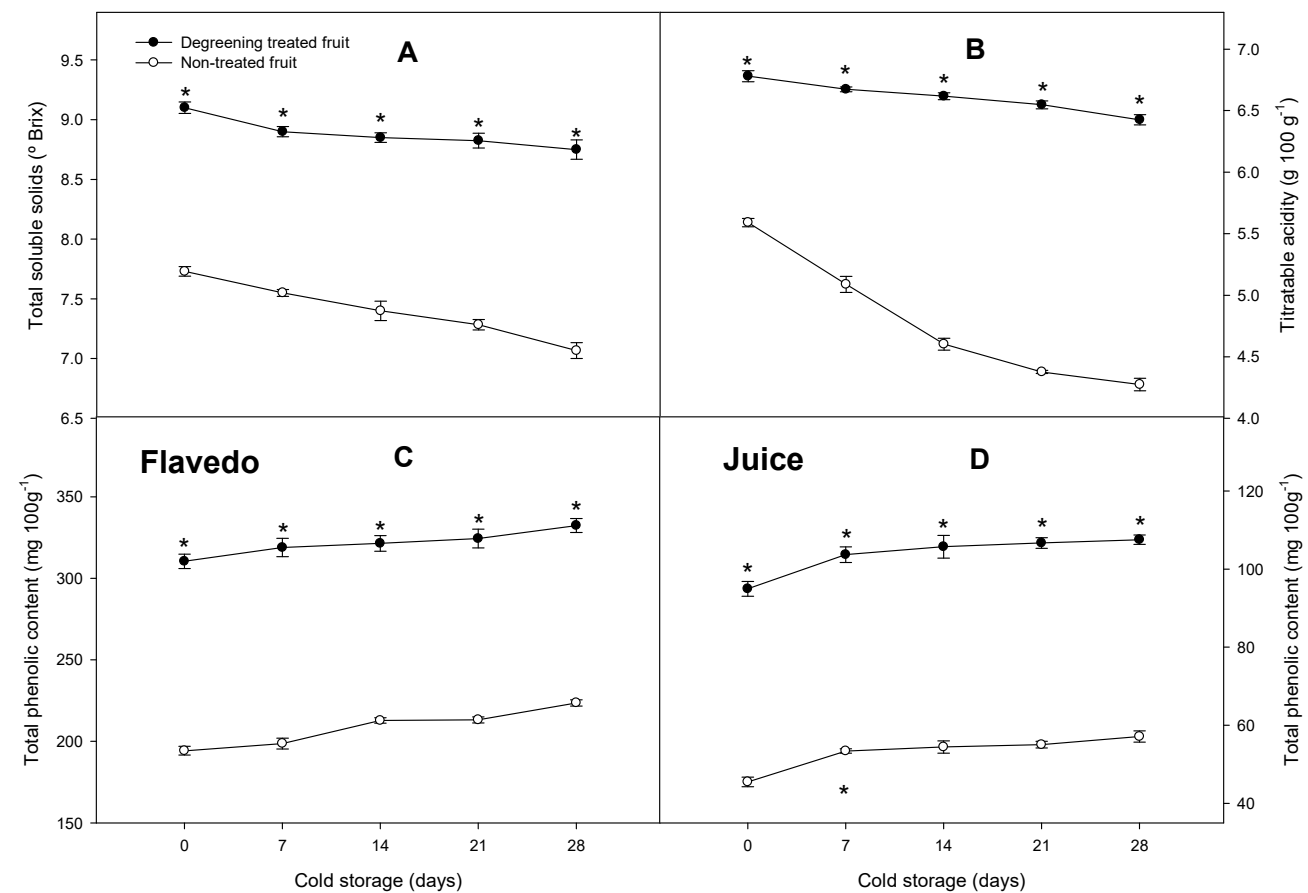

Figure 5. Effect of degreening treatment on total soluble solids (A), titratable acidity (B), and total phenolic content in flavedo (C) and juice (D) in lemon fruits stored for 28 days at $10{ }^{\circ} \mathrm{C}$. Asterisks $\left(^{*}\right)$ show significant differences between treated and non-treated fruits at $p<0.05$.

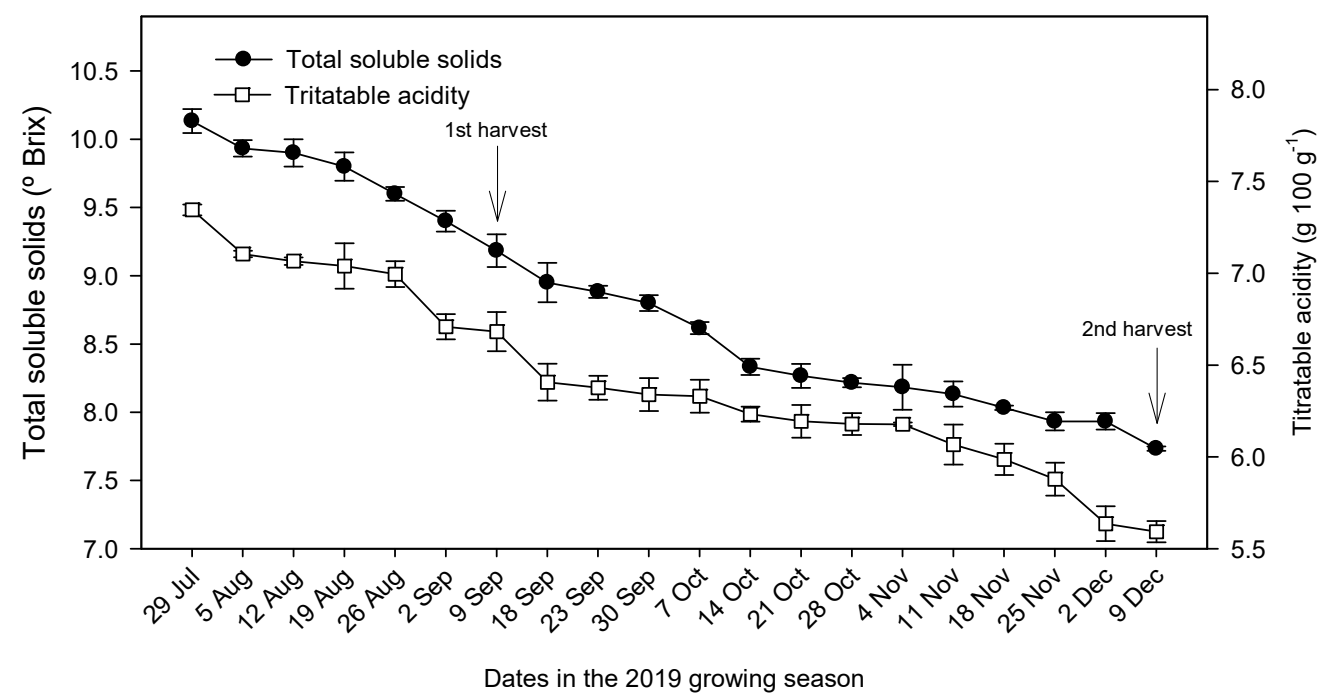

Figure 6. Evolution of total soluble solids and titratable acidity content at the left and right axes, respectively, in lemon fruits during development and on-tree ripening in the 2019 growing season.

Phenolic compounds are directly related to fruit antioxidant properties, free radicals that are produced during the fruit senescence process. Therefore, a higher concentration 
of total phenolics in fruit tissues could help with maintaining an optimal quality during extended cold storage [15]. The total phenolic content (TPC) was significantly higher $(p<0.05)$ in flavedo and juice samples of degreening-treated lemon fruits compared to non-treated at day 0 (Figure $5 \mathrm{C}, \mathrm{D}$, respectively), those differences being maintained during postharvest storage. The increase observed in TPC during cold storage could be related to the stimulation of the phenylalanine ammonium lyase (PAL) activity, a key enzyme involved in the biosynthesis of phenolics [39]. These functional results are in accordance with several previous studies carried out in lemons [15,40,41], plums [42], cherries [43], and pomegranate fruits [44].

At day 0 , the differences in TPC observed between both treatments for flavedo and juice samples (Figure 5C,D, respectively) could be related to the decrease in this parameter observed at the second harvest date compared to the first one during the developmental cycle (Figure 7). A 40\% decrease in TPC in flavedo tissue was observed, being greater in the juice sample, with a decrease of $58 \%$, approximately. This evolution follows previous results reported on TPC in 'Verna', 'Akragas', and 'Fino' lemon cultivars at different development stages $[45,46]$. The decrease in TPC could be associated with an increase in polyphenol oxidase enzyme activity [47]. Lemon fruits showed important physico-chemical changes during the development and on-tree ripening and, despite being a non-climacteric fruit, also during postharvest storage. Moreover, the results indicated that on-tree fruit ripening promotes the fruit senescence process, this fact being related to a possible increase in fruit metabolic activity. It is important to highlight that optimising the harvest point could improve the organoleptic and functional quality of lemon fruits during their postharvest storage. For instance, the ratio of TSS and TA content could affect the flavour of lemons and the energy available to maintain normal cell function [2,15]. Finally, another important factor is the decrease in TPC observed in preharvest lemons, since the later harvested lemons could have increased susceptibility to postharvest diseases caused by phytopathogenic fungi $[44,46,48]$.

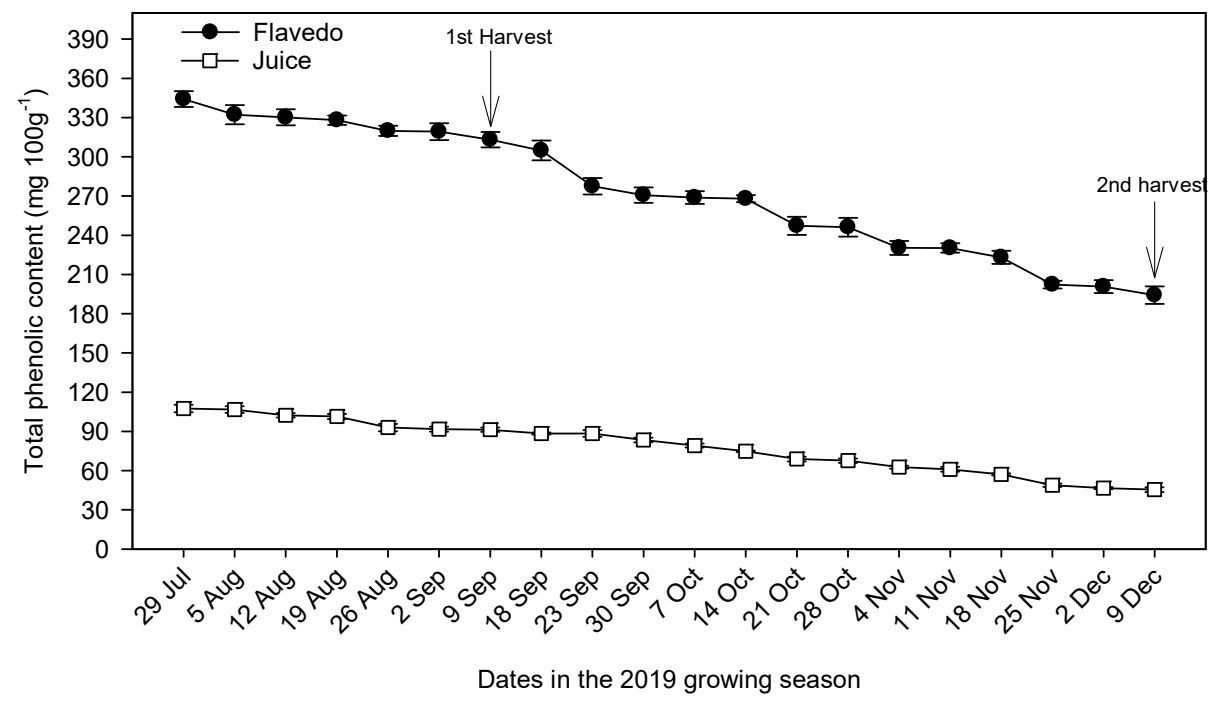

Figure 7. Evolution of the total phenolic content in flavedo and juice samples in lemon fruits during development and on-tree ripening in the 2019 growing season.

\section{Conclusions}

The degreening treatment did not have a negative effect on the physico-chemical and sensory fruit quality during postharvest cold storage and the on-tree ripening process. Lemon fruits harvested at the beginning of the growing season with the optimal physico-chemical characteristics maintained their quality parameters despite the severe environmental conditions during the degreening treatment. These results have demonstrated that the degreening process, applied on green lemon fruits of early cultivars, is a useful tool to achieve the yellow colour demanded by consumers. In addition, these results could 
be used as a practical application for the establishment of some key points during on-tree fruit ripening when the degreening process is applied.

Author Contributions: Conceptualisation, V.S.-E. and P.J.Z.; methodology, M.J.G. and M.E.G.-P.; software, A.D.-S.; validation, V.S.-E., M.E.G.-P., M.J.G. and S.P.-P.; formal analysis, V.S.-E.; investigation, V.S.-E., S.P.-P. and A.D.-S.; resources, P.J.Z.; data curation, V.S.-E.; writing-original draft preparation, V.S.-E.; writing—review and editing, V.S.-E., M.J.G., M.E.G.-P. and P.J.Z.; visualisation, V.S.-E.; supervision, V.S.-E. and P.J.Z.; project administration, P.J.Z.; funding acquisition, P.J.Z. All authors have read and agreed to the published version of the manuscript.

Funding: This research received no external funding.

Institutional Review Board Statement: Not applicable.

Informed Consent Statement: Not applicable.

Data Availability Statement: Data is contained within the article.

Conflicts of Interest: The authors declare no conflict of interest.

\section{References}

1. Smith, O.M.; Cohen, A.L.; Rieser, C.J.; Davis, A.G.; Taylor, J.M.; Adesanya, A.W.; Jones, M.S.; Meier, A.R.; Reganold, J.P.; Orpet, R.J.; et al. Organic farming provides reliable environmental benefits but increases variability in crop yields: A global meta-analysis. Front. Sustain. Food Syst. 2018, 3, 82. [CrossRef]

2. Campbell, B.L.; Nelson, R.G.; Ebel, R.C.; Dozier, W.A.; Adrian, J.L.; Hockema, B.R. Fruit quality characteristics that affect consumer preferences for satsuma mandarins. HortScience 2004, 39, 1664-1669. [CrossRef]

3. Ministerio de Agricultura, Pesca y Alimentación (MAPA). Informe Anual de Resultados para los Cultivos Ecológicos 12 Octubre 2020. Available online: https://www.mapa.gob.es/es/alimentacion/temas/produccion-eco/informeanual202 Oproduccionecologica_tcm30-551456.pdf (accessed on 12 November 2021).

4. Willner, H. The World of the Organic Agriculture 2021; Trávníček, J., Meier, C., Schlatter, B., Eds.; FiBL \& IFOAM Press: Frick, Switzerland, 2021. Available online: https:/ / www.fibl.org/fileadmin/documents/shop/1150-organic-world-2021.pdf (accessed on 12 November 2021).

5. Conesa, A.; Brotons, J.M.; Manera, F.J.; Porras, I. The degreening of lemon and grapefruit in ethylene atmosphere: A cost analysis. Sci. Hort. 2004, 179, 140-145. [CrossRef]

6. Mitalo, O.W.; Otsuki, T.; Okada, R.; Obitsu, S.; Masuda, K.; Hojo, Y.; Matsuura, T.; Mori, I.C.; Abe, D.; Asiche, W.O.; et al. Low temperature modulates natural peel degreening in lemon fruit independently of endogenous ethylene. J. Exp. Bot. 2020, 71, 4778-4796. [CrossRef] [PubMed]

7. Hu, Y.; Wang, G.; Pan, S.; Wang, L. Influence of ethylene and ethephon treatments on the peel color and carotenoids of Gannan Newhall navel orange during postharvest storage. J. Food Biochem. 2018, 42, e12534. [CrossRef]

8. Mayuoni, L.; Tietel, Z.; Patil, B.S.; Porat, R. Does ethylene degreening affect internal quality of citrus fruit? Postharvest Biol. Technol. 2011, 62, 50-58. [CrossRef]

9. Tietel, Z.; Plotto, A.; Fallik, E.; Lewinsohn, E.; Porat, R. Taste and aroma of fresh and stored mandarins. J. Sci. Food Agric. 2011, 91, 14-23. [CrossRef] [PubMed]

10. Baldwin, E.A.; Bai, J.; Plotto, A.; Ritenour, M.A. Citrus fruit quality assessment; producer and consumer perspectives. Stewart Postharvest Rev. 2014, 10, 1-7.

11. Sdiri, S.; Rambla, J.L.; Besada, C.; Granell, A.; Salvador, A. Changes in the volatile profile of citrus fruit submitted to postharvest degreening treatment. Postharvest Biol. Technol. 2017, 133, 48-56. [CrossRef]

12. Ladaniya, M.S.; Singh, S. Use of ethylene gas for degreening of sweet orange (Citrus sinenesis Osbeck) cv. Mosambi. J. Sci. Ind. Res. 2001, 60, 662-667.

13. Sdiri, S.; Navarro, P.; Monterde, A.; Benabda, J.; Salvador, A. New degreening treatments to improve the quality of citrus fruit combining different periods with and without ethylene exposure. Postharvest Biol. Technol. 2012, 63, 25-32. [CrossRef]

14. Julhia, L.; Belmin, R.; Meynard, J.M.; Pailly, O.; Casabianca, F. Acidity Drop and Coloration in Clementine: Implications for Fruit Quality and Harvesting Practices. Front. Plant Sci. 2019, 10, 754. [CrossRef]

15. Serna-Escolano, V.; Martínez-Romero, D.; Giménez, M.J.; Serrano, M.; García-Martínez, S.; Valero, D.; Valverde, J.M.; Zapata, P.J. Enhancing antioxidant systems by preharvest treatments with methyl jasmonate and salicylic acid leads to maintain lemon quality during cold storage. Food Chem. 2021, 338, 128044. [CrossRef]

16. Iglesias, D.J.; Cercós, M.; Colmenero-Flores, J.M.; Naranjo, M.A.; Rios, G.; Carrera, E. Physiology of citrus fruiting. Braz. J. Plant Physiol. 2007, 19, 333-362.

17. Ballester, C.; Castel, J.; El-Mageed, T.A.A.; Castel, J.R.; Intrigliolo, D.S. Long-term response of “Clementina de Nules” citrus trees to summer regulated deficit irrigation. Agric. Water Manag. 2014, 138, 78-84. [CrossRef] 
18. Lin, Q.; Qian, J.; Zhao, C.; Wang, D.; Liu, C.; Wang, Z. Low temperature induced changes in citrate metabolism in ponkan (Citrus reticulata blanco cv. ponkan) fruit during maturation. PLoS ONE 2016, 11, e0156703. [CrossRef] [PubMed]

19. Strano, M.C.; Di Silvestro, S.; Allegra, M.; Russo, G.; Caruso, M. Effect of cold storage on the postharvest quality of different Tarocco sweet orange clonal selections. Sci. Hort. 2021, 285, 110167. [CrossRef]

20. Haider, S.T.; Ahmad, S.; Anjum, M.A. Effects of different postharvest techniques on quality management and shelf life of 'Kinnow' mandarin fruit. Food Meas. 2021, 15, 2549-2561. [CrossRef]

21. Valverde, J.M.; Giménez, M.J.; Guillén, F.; Valero, D.; Martínez-Romero, D.; Serrano, M. Methyl salicylate treatments of sweet cherry trees increase antioxidant systems in fruit at harvest and during storage. Postharvest Biol. Technol. 2015, 109, 106-113. [CrossRef]

22. Martínez-Esplá, A.; Zapata, P.J.; Valero, D.; Martínez-Romero, D.; Díaz-Mula, H.M.; Serrano, M. Preharvest treatments with salicylates enhance nutrient and antioxidant compounds in plum at harvest and after storage. J. Sci. Food Agric. 2018, 98, 2742-2750. [CrossRef]

23. García-Pastor, M.; Serrano, M.; Guillén, F.; Giménez, M.J.; Martínez-Romero, D.; Valero, D.; Zapata, P.J. Preharvest application of methyl jasmonate increases crop yield, fruit quality and bioactive compounds in pomegranate 'Mollar de Elche' at harvest and during postharvest storage. J. Sci. Food Agric. 2020, 100, 145-153. [CrossRef]

24. Habibi, F.; Ramezanian, A.; Guillén, F.; Serrano, M.; Valero, D. Blood oranges maintain bioactive compounds and nutritional quality by postharvest treatments with $\gamma$-aminobutyric acid, methyl jasmonate or methyl salicylate during cold storage. Food Chem. 2020, 15, 125634. [CrossRef]

25. Manera, F.C.; Brotons, J.M.; Conesa, A.; Porras, I. Relationship between air temperature and degreening of lemon (Citrus lemon L. Burm. F.) peel color during maturation. Aust. J. Crop. Sci. 2012, 6, 10.

26. Poole, N.D.; Gray, K. Quality in citrus fruit: To degreen or not degreen? Br. Food J. 2002, 104, 492-505. [CrossRef]

27. Wardowski, W. Degreening. Packinghouse Newslett. 1985, 141, 2-3.

28. Morales, J.; Tárrega, A.; Salvador, A.; Navarro, P.; Besada, C. Impact of ethylene degreening treatment on sensory properties and consumer response to citrus fruits. Int. Food Res. 2020, 127, 108641. [CrossRef]

29. Kays, S.J.; Paul, R.R. Stress in Harvested Products; Kays, S.J., Paul, R.R., Eds.; Exon Press: Athens, Greece, $2004 ;$ pp. $355-414$.

30. Cohen, E.; Schiffmann-Nadel, M. Storage capability at different temperatures of lemons grown in Israel. Sci. Hort. 1978, 9 , 251-257. [CrossRef]

31. Brizzolara, S.; Manganaris, G.A.; Fotopoulos, V.; Watkins, C.B.; Tonutti, P. Primary Metabolism in Fresh Fruits During Storage. Front. Plant Sci. 2020, 11, 80. [CrossRef]

32. Grierson, W. Maturity and Grade Standards. In Fresh Citrus Fruits, 2nd ed.; Wardowsk, W.F., Miller, W.N., Hall, D.J., Grierson, W., Eds.; Source Inc.: Longboat Key, FL, USA, 2004; pp. 23-48.

33. Rasouli, M.; Koushesh-Saba, M.; Ramezanian, A. Inhibitory effect of salicylic acid and Aloe vera gel edible coating on microbial load and chilling injury of orange fruit. Sci. Hort. 2019, 247, 27-34. [CrossRef]

34. Venkatachalam, K.; Meenune, M. Effect of methyl jasmonate on physiological and biochemical quality changes of longkong fruit under low temperature storage. Fruits 2015, 70, 69-75. [CrossRef]

35. Gil-Izquierdo, A.; Riquelme, M.T.; Porras, I.; Ferreres, F. Effect of the Rootstock and Interstock Grafted in Lemon Tree (Citrus limon (L.) Burm.) on the flavonoid content of lemon juice. J. Agric. Food Chem. 2004, 52, 324-331. [CrossRef]

36. Di Matteo, A.; Di Rauso-Simeone, G.; Cirillo, A.; Rao, M.A.; Di Vaio, C. Morphological characteristics, ascorbic acid and antioxidant activity during fruit ripening of four lemon (Citrus limon (L.) Burm. F.) cultivars. Sci. Hort. 2021, 276, 109741. [CrossRef]

37. Sun, Y.; Singh, Z.; Tokala, Y.; Heather, B. Harvest maturity stage and cold storage period influence lemon fruit quality. Sci. Hort. 2019, 249, 322-328. [CrossRef]

38. Barberis, A.; Cefola, M.; Pace, B.; Azara, E.; Spissu, Y.; Serra, P.A.; Logrieco, A.F.; D’Hallewin, G.; Fadda, A. Postharvest application of oxalic acid to preserve overall appearance and nutritional quality of fresh-cut green and purple asparagus during cold storage: A combined electrochemical and mass-spectrometry analysis approach. Postharvest Biol. Technol. 2019, 148, 158-167. [CrossRef]

39. Ruiz-García, Y.; Gómez-Plaza, E. Elicitors: A tool for improving fruit phenolic content. Agriculture 2013, 3, 33-52. [CrossRef]

40. Siboza, X.I.; Bertling, I.; Odindo, A.O. Salicylic acid and methyl jasmonate improve chilling tolerance in cold-stored lemon fruit (Citrus limon). J. Plant Physiol. 2014, 171, 1722-1731. [CrossRef]

41. Serna-Escolano, V.; Valverde, J.M.; García-Pastor, M.E.; Valero, D.; Castillo, S.; Guillén, F.; Martínez-Romero, D.; Zapata, P.J.; Serrano, M. Pre-harvest methyl jasmonate treatments increase antioxidant systems in lemon fruit without affecting yield or other fruit quality parameters. J. Sci. Food Agric. 2019, 99, 5035-5043. [CrossRef]

42. Zapata, P.; Martínez-Esplá, A.; Guillén, F.; Díaz-Mula, H.M.; Martínez-Romero, D.; Serrano, M.; Valero, D. Preharvest application of methyl jasmonate (MeJA) in two plum cultivars. 2. Improvement of fruit quality and antioxidant systems during postharvest storage. Postharvest Biol. Technol. 2014, 98, 115-122. [CrossRef]

43. Gimenez, M.J.; Serrano, M.; Valverde, J.M.; Martinez-Romero, D.; Castillo, S.; Valero, D.; Guillen, F. Preharvest salicylic acid and acetylsalicylic acid treatments preserve quality and enhance antioxidant systems during postharvest storage of sweet cherry cultivars. J. Sci. Food Agric. 2017, 97, 1220-1228. [CrossRef] [PubMed] 
44. Garcia-Pastor, M.E.; Zapata, P.J.; Castillo, S.; Martinez-Romero, D.; Guillen, F.; Valero, D.; Serrano, M. The effects of salicylic acid and its derivatives on increasing pomegranate fruit quality and bioactive compounds at harvest and during storage. Front. Plant Sci. 2020, 11, 668. [CrossRef]

45. Multari, S.; Licciardello, C.; Caruso, M.; Martens, S. Monitoring the changes in phenolic compounds and carotenoids occurring during fruit development in the tissues of four citrus fruits. Food Res. Int. 2020, 134, 109228. [CrossRef] [PubMed]

46. Serna-Escolano, V.; Gimenez, M.J.; Castillo, S.; Valverde, J.M.; Martínez-Romero, D.; Guillén, F.; Serrano, M.; Valero, D.; Zapata, P.J. Preharvest Treatment with Oxalic Acid Improves Postharvest Storage of Lemon Fruit by Stimulation of the Antioxidant System and Phenolic Content. Antioxidants 2021, 10, 963. [CrossRef] [PubMed]

47. Dong, X.; Hu, Y.; Li, Y.; Zhou, Z. The maturity degree, phenolic compounds antioxidant activity of Eureka lemon [Citrus limon (L.) Burm. f.]: A negative correlation between total phenolic content, antioxidant capacity and soluble solid content. Sci. Hort. 2019, 243, 281-289. [CrossRef]

48. Castillo, A.; Meitha, K.; Pramesti, Y.; Suhandono, S. Reactive oxygen species and antioxidants in postharvest vegetables and fruits. Int. J. Food Sci. 2020, 2020, 8817778. 